\title{
PERILAKU PENCARIAN INFORMASI MAHASISWA TINGKAT AKHIR FAKULTAS EKONOMI DAN ILMU SOSIAL DI PERPUSTAKAAN UNIVERSITAS SARI MUTIARA INDONESIA
}

\author{
Ida Mariani Pasaribu ${ }^{1}$, Muhammad Rasyid Ridlo ${ }^{2}$, Herry Fernando Tarigan ${ }^{3}$ \\ ${ }^{1}$ Universitas Sari Mutiara Indonesia, Medan, Indonesia \\ ${ }^{2}$ Universitas Sumatera Utara, Program Studi Ilmu Perpustakaan \\ rasyidridlo28@gmail.com
}

\begin{abstract}
This study aims to determine information seeking behavior by final-level students of the Faculty of Economics and Social Sciences at the Sari Mutiara Indonesia University Library. This study uses descriptive quantitative methods. This study uses an analytical framework based on the information search behavior stage model by David Ellis which consists of: Starting, Chaining, Browsing, Differentiating, Monitoring, Extracting and ending. The results showed that there were similarities in the stages of information seeking activities according to the model proposed by David Ellis with information seeking behavior carried out by final-year students of the Faculty of Economics and Social Sciences at Sari Mutiara Indonesia University.
\end{abstract}

Keywords: Information, Information Search Behavior, Model David Ellis 


\begin{abstract}
Abstrak
Penelitian ini bertujuan untuk untuk mengetahui perilaku pencarian informasi oleh mahasiswa tingkat akhir Fakultas Ekonomi dan Ilmu Sosial di Perpustakaan Universitas Sari Mutiara Indonesia. Penelitian ini menggunakan metode deskriptif kuantitatif. Penelitian ini menggunakan kerangka analisis berdasarkan model tahapan perilaku pencarian informasi oleh David Ellis yakni terdiri dari: Starting, Chaining, Browsing, Differentiating, Monitoring, Extracting dan ending. Hasil penelitian menunjukan bahwa, terdapat kesamaan tahapan-tahapan kegiatan pencarian informasi menurut model yang dikemukakan oleh David Ellis dengan perilaku pencarian informasi yang dilakukan oleh mahasiswa tingkat akhir Fakultas Ekonomi dan Ilmu Sosial Universitas Sari Mutiara Indonesia.
\end{abstract}

Kata kunci: Informasi, Perilaku Pencarian Informasi, Model David Ellis

\title{
A. Pendahuluan
}

Pencarian informasi adalah suatu kegiatan yang dilakukan seseorang untuk mendapatkan informasi. Perilaku pencarian informasi dimulai ketika seseorang merasa bahwa pengetahuan yang dimilikinya saat itu kurang dari pengetahuan yang dibutuhkannya. Untuk memenuhi kebutuhannya maka orang tersebut akan mencari informasi dengan menggunakan berbagai sumber. Tindakan pencarian informasi menggunakan literatur adalah suatu perilaku yang kenyataannya menggambarkan berbagai tujuan. Perilaku dalam pencarian informasi diistilahkan sebagai information searching behaviour.

Peningkatan pencarian informasi merupakan fenomena yang mengindikasikan bahwa informasi telah menjadi salah satu kebutuhan hidup yang utama. Untuk memenuhi kebutuhan informasi tersebut muncul berbagai cara dan strategi yang dapat diterapkan untuk mendapatkan informasi. Akibatnya, bermacammacam perilaku pencarian informasi tampak ke permukaan. 
Seperti halnya yang dialami oleh mahasiswa yang dituntut untuk memahami seperangkat pengetahuan dan keterampilan sebagaimana yang dirumuskan dalam kurikulum, dan diwujudkan dalam bentuk matakuliah, baik matakuliah pilihan maupun mata kuliah wajib. Pada umumnya, salah satu tugas akhir mahasiswa yang ingin meraih gelar sarjana adalah menyusun karya tulis ilmiah atau yang biasa disebut skripsi.

Penulisan skripsi, mahasiswa dituntut memiliki kemandirian dalam pengerjaannya melalui proses bimbingan yang dilakukan oleh dosen pembimbing. Proses penulisan skripsi memerlukan dukungan informasi yang memadai sebagai sumber penulisannya. Demi kelancaran akhir proses belajar yang dilaluinya, mahasiswa perlu memanfaatkan sumber informasi, baik di perpustakaan ataupun unit informasi lainnya secara efektif dan efisien.

Mahasiswa memiliki perbedaan dalam menelusur informasi yang dicarinya. Perbedaan tersebut akan menghasilkan pola pikir yang dapat mempengaruhi perilaku pencarian individu. Untuk mengetahui perilaku pencarian informasi mahasiswa dalam hal menyelesaikan skripsinya maka kita harus mengetahui hal-hal apa yang dapat mempengaruhi dalam mencari suatu informasi, mulai dari seberapa pentingkah informasi tersebut sampai bagaimana mahasiswa tersebut dapat memenuhi kebutuhan informasi yang dicarinya Maka dari itu dapat disimpulkan bahwa ada banyak hal yang dapat mempengaruhi perbedaan perilaku informasi antara satu individu dengan individu lain.

Menurut Brodjonegoro (2010) bahwa "setiap perguruan tinggi baik negeri maupun swasta wajib memiliki perpustakaan dan apabila tidak memiliki perpustakaan maka akan dicabut izin berdirinya perguruan tinggi tersebut". Brodjonegoro juga menyatakan bahwa "suatu perguruan tinggi diwajibkan memiliki perpustakaan disebabkan karena peran perpustakaan sangat penting untuk menjadikan perguruan tinggi kompetitif, serta menciptakan lulusan dan karya ilmiah yang bermutu". 
Mengingat pentingnya peran perpustakaan, sebagaimana perguruan tinggi pada umumnya, Universitas Sari Mutiara Indonesia juga telah memiliki perpustakaan. Perpustakaan Universitas Sari Mutiara Indonesia menyediakan berbagai fasilitas pencarian informasi, diantaranya adalah fasilitas pencarian informasi seperti buku, jurnal, kamus, dan majalah. Dengan fasilitas pencarian informasi yang beragam ini, pemustaka dapat memilih sistem informasi yang sesuai untuk ia gunakan.

Berdasarkan hasil survei awal di Perpustakaan Universitas Sari Mutiara, diketahui bahwa sebagian besar masalah yang dihadapi oleh beberapa mahasiswa terletak di beberapa tahap pencarian informasi, yaitu browsing, monitoring, dan extracting. Hasil wawancara menunjukkan beberapa mahasiswa menyatakan bahwa pada tahap pada tahap browsing, mahasiswa sering melakukan kesalahan dalam memilih keyword (kata kunci) yang tepat saat melakukan pencarian informasi. Permasalahan yang peneliti temukan saat melakukan pengamatan terhadap mahasiswa yang sedang mencari informasi berupa jurnal untuk kebutuhan skripsinya, yaitu saat browsing, mahasiswa yang peneliti amati hanya mengetik 'topik' jurnalnya saja sebagai keyword di mesin pencarian, tanpa menggunakan keyword yang lebih terperinci, seperti judul jurnalnya secara lengkap. Akibatnya, hasil tampilan dari browsing yang dilakukan tidak berupa jurnal, melainkan tulisan-tulisan mengenai topik tersebut yang berupa blogspot. Jurnal yang diinginkan pun tidak ditemukan. Penyebab utama terjadinya masalah di atas adalah karena kebanyakan mahasiswa tidak mengerti bagaimana cara memilih keyword (kata kunci) yang benar, Hal ini tidak sesuai dengan model yang menurut Ellis.

Pada tahap monitoring, tidak adanya monitoring yang berkelanjutan terhadap koleksi jurnal yang digunakan, sehingga referensi yang digunakan tidak up to date (terkini). Seorang yang mencari informasi harus terus mengikuti perkembangan dari sumber informasi (referensi) yang digunakan.Terdapat mahasiswa yang masih menggunakan beberapa sumber referensi jurnal yang 
sudah usang. Setelah peneliti selidiki, ternyata mahasiswa tersebut tidak lagi melakukan monitoring untuk mencari sumber referensi jurnal terbaru. Mahasiswa tersebut seakan-akan telah puas dengan sumber referensi yang dia gunakan. Padahal besar kemungkinan mahasiswa ini mendapatkan referensi terbaru jika mereka terlebih dahulu melakukan monitoring terhadap referensi yang digunakan. Kegiatan monitoring sangat penting dilakukan. Hal ini untuk memastikan referensi yang digunakan selalu yang terkini atau terbaru.

Diketahui pada tahap extracting, masalah yang sering ditemukan oleh mahasiswa adalah terbatasnya koleksi buku, jurnal, dan majalah yang dimiliki perpustakaan, sehingga informasi yang dibutuhkan terkadang tidak tersedia. Terdapat beberapa mahasiswa yang sedang mencari buku tentang metode penelitian. Akan tetapi, buku tersebut tidak ditemukan sedang dipinjam oleh mahasiswa lain. Hal ini diketahui setelah mahasiswa bertanya kepada petugas perpustakaan. Permasalahan di atas kemungkinan disebabkan oleh kurang efektifnya keterampilan penelusuran informasi yang dibutuhkan, sehingga membuat mahasiswa kekurangan bahan referensi untuk menyelesaikan tugas akhir mereka. Oleh sebab itu perlu dicarika

Berdasarkan uraian di atas, tujuan dari penelitian ini adalah: untuk mengetahui perilaku pencarian informasi oleh mahasiswa tingkat akhir Fakultas Ekonomi dan Ilmu Sosial di Perpustakaan Universitas Sari Mutiara Indonesia.

\section{Metode Penelitian}

Penelitian ini merupakan penelitian deskriptif kuantitatif. Menurut Sugiyono (2010), metode deskriptif kuantitatif adalah metode yang digunakan untuk menganalisa data yang telah terkumpul sebagaimana adanya yang berlaku untuk umum. Penelitian dilakukan di Universitas Sari Mutiara Indonesia. Populasi penelitian adalah seluruh mahasiswa Fakultas Ekonomi dan Sosial tingkat akhir yang aktif terdaftar di Perpustakaan dengan jumlah 
52 orang di Universitas Sari Mutiara Indonesia. Metode penarikan sampel menggunakan metode sampel jenuh. Istilah lain dari penggunaan sampel jenuh adalah metode sensus.

Penelitian ini menggunakan dua jenis data, yaitu data primer dan data sekunder. Data primer adalah data yang diperoleh langsung dari jawaban responden dengan menggunakan kuesioner. Sedangkan data sekunder adalah data yang mendukung data primer yaitu data perilaku pencarian informasi yang diperoleh dari buku, jurnal dan dokumen lainnya yang berhubungan dengan topik yang diteliti.

Data yang diperoleh kemudian disajikan ke dalam tabel lalu dihitung persentasenya, selanjutnya data tersebut dianalisis dan diinterpretasikan. Penelitian ini menggunakan rumusan sebagai berikut:

$$
P=\frac{F}{n}
$$

dimana: $\mathrm{P}=$ Persentase, $\mathrm{F}=$ Jumlah jawaban yang diperoleh, dan $\mathrm{n}=$ Jumlah responden.

Untuk menafsirkan besarnya persentase yang dibuat dari Tabel tabulasi data, maka penulis menggunakan teori Arikunto (2006), dengan pengkategorian sebagai berikut: 1-25\% $=$ Sebagian kecil, 26-49\% = Hampir setengah, 50\% = Setengah, $51-75 \%=$ Sebagian besar, $76-99 \%=$ Pada umumnya dan $100 \%=$ Seluruhnya.

\section{B. Pembahasan}

\section{Starting}

Starting merupakan proses memulai pencarian informasi. Perilaku pencarian informasi mahasiswa Fakultas Ekonomi dan Ilmu Sosial tingkat akhir saat melakukan starting dapat dilihat dari angket pernyataan yang terdiri dari: 1) saudara menentukan topik yang akandicari sebelum melakukan pencarian informasi, 2) saudara menyadari kebutuhan informasi saudara ketika mengikuti 
perkuliahan, dan 3) saudara bertanya kepada seseorang ahli tentang informasi yang saudara butuhkan.

Dari 52 responden yang disurvei, responden paling banyak menyatakan: setuju terhadap pernyataan 1 (28 responden atau $53,8 \%$ ), pernyataan 2 (29 responden atau $55,8 \%$ ), dan pernyataan 3 (24 responden atau 46,2\%). Hal ini menunjukkan bahwa sebagian besar mahasiswa Fakultas Ekonomi dan Ilmu Sosial Tingkat akhir menentukan topik yang akan dicari sebelum melakukan pencarian informasi. Mereka selalu mempersiapkan topik yang akan dicari sebelum ke perpustakaan

Selain itu, sebagian besar dari mahasiswa Fakultas Ekonomi dan Ilmu Sosial Tingkat akhir ini juga menyadari informasi yang mereka butuhkan ketika mengikuti perkuliahan. Hal ini sejalan dengan apa yang diungkapkan Riani (2017) bahwa sebelum melakukan pencarian informasi, maka terlebih dahulu pencari informasi harus mengetahui kebutuhan-kebutuhan informasi. Dengan mereka mengetahui informasi yang mereka butuhkan, maka mahasiswa akan melakukan pencarian informasi ke perpustakaan sebelum mengikuti perkuliahan.

Hasil analisis juga menunjukkan hampir setengah mahasiswa Fakultas Ekonomi dan Ilmu Sosial tingkat akhir bertanya kepada seorang ahli informasi untuk mendapatkan informasi yang dibutuhkan. Hal ini mengindikasikan bahwa mahasiswa Fakultas Ekonomi dan Ilmu Sosial tingkat akhir lebih terarah untuk mendapatkan informasi yang diperoleh dengan bertanya pada ahli informasi.

\section{Chaining}

Chaining merupakan kegiatan pengguna informasi melakukan pencarian informasi yang mengarah kepada informasi yang dibutuhkan. Dalam hal ini pengguna dapat meminta bantuan kepada seorang pustakawan atau dengan menggunakan sumber informasi sekunder seperti katalog perpustakaan, indeks dan abstrak yang merupakan sumber informasi yang dapat membantu 
pencari informasi menemukan informasi yang dibutuhkan. Saat melakukan chaining dapat dilihat dari angket pernyataan yang terdiri dari: 1) Saudara menggunakan katalog ketika mencari informasi di perpustakaan, 2) Saudara membutuhkan bantuan seorang pustakawan dalam mencari informasi, 3) Saudara menulis hal-hal yang dianggap penting dalam sebuah catatan kecil.

Hasil survei menunjukkan mayoritas responden (26 responden atau 50,0\%) menjawab setuju menggunakan katalog ketika mencari informasi di perpustakaan. Dari jawaban responden ini diketahui jika mahasiswa berpandangan bahwa salah satu sumber informasi sekunder di perpustakaan adalah katalog, jurnal, majalah. Dengan menggunakan katalog, mahasiswa dapat menemukan informasi yang dibutuhkan lebih cepat dan juga dapat menemukan lebih banyak sumber informasi lain yang membahas topik yang sama dengan kebutuhan.

Mayoritas responden (24 responden atau 46,2\%) juga menyatakan setuju membutuhkan bantuan seorang pustakawan dalam mencari informasi. Hal ini menunjukkan bahwa hampir setengah mahasiswa Fakultas Ekonomi dan Ilmu Sosial Tingkat akhir membutuhkan bantuan seorang pustakawan dalam mencari informasi. Seorang pustakawan memiliki peran penting dalam penyebaran informasi di sebuah perpustakaan. Para pencari informasi mengetahui bahwa seorang pustakawan dapat membantu mereka menemukan informasi yang dibutuhkan.

Untuk pernyataan 3, mayoritas responden (26 responden atau 50,0\%) menyatakan setuju menulis hal-hal yang dianggap penting dalam sebuah catatan kecil. Hal ini menunjukkan bahwa setengah mahasiswa Fakultas Ekonomi dan Ilmu Sosial tingkat akhir mencatat hal-hal penting yang berkaitan dengan informasi yang dicari saat berada di perpustakaan, hal ini membantu mahasiswa untuk tetap mengingat informasi-informasi penting yang telah di dapatkan selama dalam mencari informasi. Hal ini sesuai dengan teori Ellis tentang perilaku pencarian informasi. 


\section{Browsing}

Browsing merupakan tahap kegiatan yang ditandai dengan kegiatan pencarian informasi dengan cara penelusuran semi tersruktur telah mengarah pada bidang yang diamati. Kegiatan pada tahap ini efektif untuk mengetahui tempat-tempat yang menjadi sasaran potensi untuk ditelusuri, perilaku pencarian informasi mahasiswa fakultas ekonomi dan ilmu sosial tingkat akhir saat melakukan browsing dapat dilihat dari angket pernyataan yang terdiri dari: 1) Saudara mengidentifikasi queri (kata kunci) yang memungkinkan informasi terpanggil sebelum melakukan pencarian di internet. 2) Internet adalah sumber informasi utama bagi Saudara. 3)Saudara menggunakan bantuan penelusuran operator boolean ketika melakukan pencarian. 4) Saudara melakukan pencarian informasi hanya pada bidang yang diamati saja.

Dari 52 responden yang disurvei, mayoritas responden (20 responden atau $38,5 \%$ ) menyatakan setuju mengidentifikasi query (kata kunci) yang memungkinkan informasi terpanggil sebelum melakukan pencarian di internet. Hal ini menunjukkan bahwa hampir setengah mahasiswa Fakultas Ekonomi dan Ilmu Sosial akhir mengidentifikasi query yang memungkinkan informasi terpanggil sebelum melakukan pencarian di internet.

Untuk pernyataan 2, mayoritas responden (23 responden atau 44,2\%) menyatakan setuju bahwa Internet adalah sumber informasi utama. Hal ini menunjukkan bahwa hampir setengah mahasiswa Fakultas Ekonomi dan Ilmu Sosial tingkat akhir menggunakan internet sebagai sumber informasi utama. Hal ini sejalan dengan penelitian Dewi dan Prahatmaja (2012) yang melakukan penelitian terhadap member ELF Bandung. Mereka menemukan bahwa member ELF Bandung menjadikan internet sebagai media informasi utama karena kemudahan, kecepatan dan keragaman bentuk informasinya.

Internet membantu mahasiswa dalam mencari informasi yang di butuhkan dalam mengerjai tugas-tugas perkuliahan. Seperti diungkapkan Oetomo yang dikutip oleh Muthoin (2014), terdapat 
beberapa keuntungan penggunaan internet oleh mahasiswa, yaitu: pertama, banyak bahan bacaan dan juga hasil penelitian yang tersedia,. Kedua, pengguna dapat menggunakan internet selama 24 jam dan dapat membaca dengan jumlah yang tidak terbatas. Ketiga, pengguna bias mendapatkan softcopy.

Untuk pernyataan 3, mayoritas responden (20 reponden atau 38,5\%) menyatakan setuju menggunakan bantuan penelusuran operator boolean ketika melakukan pencarian. Hal ini menunjukkan bahwa hampir setengah mahasiswa Fakultas Ekonomi dan Ilmu Sosial tingkat akhir menggunakan bantuan penelusuran operator boolean ketika melakukan pencarian informasi. Bantuan penelusuran seperti operator Boolean, truncation, dan proximity merupakan bantuan terhadap pencari informasi menemukan informasi dengan menggunakan basis data.

Untuk pernyataan 4, mayoritas responden (23 responden atau 44,2\%) menyatakan kurang setuju melakukan pencarian informasi hanya pada bidang yang diamati saja. Hal ini menunjukkan bahwa hampir setengah mahasiswa Fakultas Ekonomi dan Ilmu Sosial tingkat akhir tidak melakukan pencarian informasi hanya pada bidang yang diamati saja. Artinya, mereka juga mencari informasi mengenai hal-hal lain yang memiliki kaitan dengan bidang yang diamati, sehingga informasi yang didapatkan lebih luas dan lengkap. Hal ini sesuai dengan teori Ellis tentang perilaku pencarian informasi.

\section{Differentiating}

Perilaku pencarian informasi berkaitan dengan kriteria sumber informasi yang dipilih, pengguna informasi menilai dan memilih sumber informasi yang relevan dengan kebutuhan informasi. Pendapat responden terhadap pernyataan menentukan kriteria terhadap sumber informasi yang mengoleksi informasi yang dicari dapat dilihat pada pernyataan: 1) Saudara menentukan kriteria terhadap sumber informasi yang mengoleksi informasi yang saudara cari. 2) Saudara selalu memilih data yang berasal 
dari sumber relevan dan terpercaya. 3) Saudara memeringkat hasil penelusuran untuk menentukan dokumen yang benar-benar relevan dengan topik yang anda butuhkan. 4) Saudara mencari sumber informasi pada subjek-subjek yang dipilih saja.

Dari 52 responden yang disurvei, mayoritas responden (26 responden atau 50,0\%) menyatakan setuju menentukan kriteria terhadap sumber informasi yang mengoleksi informasi. Hal ini menunjukkan bahwa setengah mahasiswa Fakultas Ekonomi dan Ilmu Sosial tingkat akhir menentukan kriteria terhadap sumber informasi yang mengoleksi informasi yang mereka cari. Untuk menentukan kriteria terhadap sumber informasi yang mengoleksi informasi yang dibutuhkan, mahasiswa harus mempunyai kemampuan untuk membedakan sumber-sumber informasi yang paling relevan dengan kebutuhan informasi. Sumber informasi dapat dinilai dari: kemudahan akses, Kuantitas informasi, Relevansi hasil penelusuran.

Untuk pernyataan 2, mayoritas responden (29 responden atau $55,8 \%$ ) menyatakan setuju selalu memilih data yang berasal dari sumber relevan dan terpercaya. Hal ini menunjukkan bahwa sebagian besar mahasiswa Fakultas Ekonomi dan Ilmu Sosial tingkat akhir selalu memilih data yang berasal dari sumber relevan dan terpercaya. Tugas akhir yang dikerjakan oleh responden sangat terpercaya, dan secara ilmiah dapat digunakan sebagai bahan referensi.

Untuk pernyataan 3, mayoritas responden (21 responden atau 40,4\%) menyatakan kurang setuju memeringkat hasil penelusuran untuk menentukan dokumen yang benar-benar relevan dengan topik yang dibutuhkan. Hal ini menunjukkan bahwa sebagian besar mahasiswa fakultas ekonomi dan ilmu sosial tingkat akhir tidak memeringkat hasil penelusuran untuk menentukan dokumen yang benar-benar relevan dengan topik yang dibutuhkan. Akibatnya, mahasiswa kemungkinan besar menggunakan informasi yang kurang relevan dengan topik yang dicari sebagai referensi skripsi atau tugas akhir. 
Untuk pernyataan 4, mayoritas responden (21 reponden atau 40,4\%) menyatakan kurang setuju mencari sumber informasi pada subjek-subjek yang dipilih saja. Hal ini menunjukkan bahwa hampir setengah mahasiswa Fakultas Ekonomi dan Ilmu Sosial tingkat akhir tidak mencari sumber informasi pada subjek-subjek yang dipilih saja. Sehingga cakupan pencarian informasi mahasiswa tidak hanya pada topik yang ditentukan saja,melainkan melebar pada topik-topik lain yang dirasa berkaitan dengan topik yang sedang dicari. Hal ini sesuai dengan teori Ellis tentang perilaku pencarian informasi.

\section{Monitoring}

Merupakan kegiatan yang ditandai dengan kegiatan memantau perkembangan yang terjadi terutama dalam bidang yang diminati dengan cara mengikuti sumber teratur. Perilaku pencarian informasi mahasiswa Fakultas Ekonomi dan Ilmu Sosial tingkat akhir saat melakukan monitoring dapat dilihat dari angket pernyataan yang terdiri dari: 1) Saudara selalu mengikuti informasi terbaru tentang topik yang saudara cari. 2) Saudara selalu tertarik membaca buku dan jurnal-jurnal terbaru. 3) Saudara melihat daftar terbitan buku dan jurnal-jurnal secara berkala.

Dari 52 responden yang disurvei, mayoritas responden 26 responden $(50,0 \%)$ menyatakan setuju selalu mengikuti informasi terbaru tentang topik yang dicari. Hal ini menunjukkan bahwa setengah mahasiswa Fakultas Ekonomi dan Ilmu Sosial tingkat akhir selalu mengikuti informasi terbaru tentang topik yang dicari, Pencari informasi seharusnya memperhatikan informasi terbaru yang berhubungan dengan topik yang dibutuhkan.

Untuk pernyataan 2, mayoritas responden (29 responden atau 55,8\%) menyatakan kurang setuju tertarik membaca buku dan jurnal-jurnal terbaru. Hal ini menunjukkan bahwa sebagian besar mahasiswa Fakultas Ekonomi dan Ilmu Sosial tingkat akhir tidak tertarik membaca buku dan jurnal-jurnal terbaru. Hal ini menyebabkan mahasiswa akan ketinggalan ilmu-ilmu pengetahuan 
terbaru. Hal ini dapat mempengaruhi hasil tugas dan penelitian mahasiswa, karena jurnal pendukung yang digunakan untuk karya penelitian kemungkinan besar tidak up to date. Hal ini tidak sesuai dengan tahap pencarian Ellis yang menyatakan bahwa pengguna informasi harus tetap memperhatikan informasi terbaru.

Untuk pernyataan 3, mayoritas responden (32 responden atau 61,5) menyatakan kurang setuju melihat daftar terbitan buku dan jurnal-jurnal secara berkala. Hal ini menunjukkan bahwa sebagian besar mahasiswa Fakultas Ekonomi dan Ilmu Sosial tingkat akhir tidak melihat daftar terbitan buku dan jurnal-jurnal secara berkala, sehingga jurnal pendukung yang digunakan mahasiswa untuk karya penelitian kemungkinan besar tidak up to date.

\section{Extracting}

Sumber-sumber informasi banyak jenisnya seperti buku, majalah, surat kabar, dan media rekam informasi lainnya. Salah satu tempat yang menyediakan informasi tersebut adalah perpustakaan. perilaku pencarian informasi mahasiswa Fakultas Ekonomi dan Ilmu Sosial tingkat akhir saat melakukan extracting dapat dilihat dari angket pernyataan yang terdiri dari: 1) Perpustakaan selalu dapat memenuhi kebutuhan informasi saudara. 2) Saudara langsung mencari informasi di internet apabila informasi yang saudara cari tidak ditemukan di sumber informasi tercetak. 3) Saudara lebih memilih jurnal dari sumber terpercaya sebagai sumber informasi.

Dari 52 responden yang disurvei, mayoritas responden (26 reponden atau 50,0\%) menyatakan kurang setuju Perpustakaan selalu dapat memenuhi kebutuhan informasi. Hal ini menunjukkan bahwa mahasiswa Fakultas Ekonomi dan Ilmu Sosial tingkat akhir tidak menjadikan perpustakaan sebagai sumber informasi utama. Mahasiswa Fakultas Ekonomi dan Ilmu Sosial tingkat akhir juga menggunakan sumber informasi lain selain perpustakaan, seperti internet. Internet memuat banyak informasi yang dapat digunakan untuk menunjang tugas-tugas perkuliahan. 
Untuk pernyataan 2, mayoritas responden (34 responden atau 65,4\%) menyatakan sangat setuju langsung mencari informasi di internet apabila informasi tidak ditemukan di sumber informasi tercetak. Hal ini menunjukkan bahwa sebagian besar mahasiswa Fakultas Ekonomi dan Ilmu Sosial tingkat akhir langsung mencari informasi di internet apabila informasi tidak ditemukan di sumber informasi tercetak. Internet dimanfaatkan sebagai informasi alternatif selain perpustakaan.

Untuk pernyataan 3, mayoritas responden (29 responden $55,8 \%$ ) menyatakan setuju menyatakan setuju memilih jurnal dari sumber terpercaya sebagai sumber informasi. sementara itu. Hal ini menunjukkan bahwa sebagian besar mahasiswa Fakultas Ekonomi dan Ilmu Sosial tingkat akhir menggunakan jurnal dari sumber terpercaya sebagai sumber informasi. hal ini membuat penelitian dan tugas-tugas perkuliahan mahasiswa lebih akurat dan terpercaya. Jurnal juga memberikan informasi terbaru dari berbagai hasil penelitian atau bahkan teori baru dari suatu hasil penelitian (Istiana dan Purwaningsih (2016). Hal ini sesuai dengan teori Ellis tentang perilaku pencarian informasi.

\section{Ending}

Pernyataan responden terhadap mengakhiri pencarian setelah informasi yang terkumpul dianggap cukup untuk memenuhi kebutuhan di dalam perkuliahan dapat dilihat dari angket pernyataan 1) Saudara mengakhiri pencarian setelah informasi yang terkumpul dianggap cukup untuk membantu saudara di dalam perkuliahan.

Dari 52 responden yang disurvei, mayoritas responden (29 responden atau 55,8\%) menyatakan setuju mengakhiri pencarian setelah informasi yang terkumpul dianggap cukup untuk membantu dalam perkuliahan. sebagian besar mahasiswa fakultas ekonomi dan ilmu sosial tingkat akhir mengakhiri pencarian setelah informasi yang terkumpul dianggap cukup untuk membantu dalam perkuliahan. Hal ini menunujukan bahwa mahasiswa mengakhiri 
pencarian informasi dengan dua kemungkinan yaitu merasa puas dengan informasi yang diperoleh atau sebaliknya. Hal ini sesuai dengan teori Ellis tentang perilaku pencarian informasi.

\section{Simpulan}

\section{Kesimpulan}

Penelitian ini bertujuan untuk mengetahui perilaku pencarian informasi oleh mahasiswa tingkat akhir fakultas ekonomi dan ilmu sosial di Perpustakaan Universitas Sari Mutiara Indonesia. Berdasarkan hasil pembahasan yang telah dilakukan, ditemukan tujuh strategi pencarian informasi dalam penelitian ini. Yaitu strategi prilaku pencarian informasi Ellis yang terdiri dari:

1. Starting, yang dilakukan oleh mahasiswa menetukan topik yang akan dicari, menyadari kebutuhan informasi dan bertanya kepada seorang ahli informasi tentang informasi yang dibutuhkan.

2. Chaining, yang dilakukan mahasiswa adalah menggunakan katalog di saat mencari informasi, dan meminta bantuan pustakawan dan menulis hal-hal yang diangap penting dalam sebuah catatan kecil saat mencari informasi di perpustakaan.

3. Browsing, yang dilakukan mahasiswa adalah mengidentifikasi qwery (kata kunci) sebelum melakukan pencarian informasi di internet dan menggunakan bantuan penelusuran operator boolean. Dalam hal ini mahasiswa menjadikan internet salah satu sumber utama informasi.

4. Differentiating, yang dilakukan mahasiswa adalah menentukan kriteria terhadap sumber informasi, memilih data yang berasal dari sumber relevan dan terpercaya. Namun mereka tidak melakukan peringkatan terhadap hasil penelusuran dokumen yang benar-benar relavan.

5. Monitoring, yang mahasiswa lakukan adalah mengikuti informasi terbaru tentang topik yang dibutuhkan. Akan tetapi mereka tidak tertarik membaca buku dan jurnal-jurnal terbaru 
serta tidak melihat daftar terbitan buku dan jurnal-jurnal secara berkala.

6. Extracting, yang mahasiswa adalah langsung mencari informasi di internet, apabila informasi yang dicari tidak ditemukan di sumber-sumber tercetak. Perpustakaan bukanlah satu-satunya sumber informasi yang dapat memenuhi kebutuhan informasi mereka.

7. Ending, yang mahasiswa lakukan dalah mengakhiri pencarian informasi setelah cukup untuk membantu di dalam perkuliahan.

Hasil penelitian ini sejalan dengan penelitian Solehat et al. (2016), Riady (2013), dan Herlina et al. (2015), yaitu adanya kesamaan tahapan-tahapan kegiatan pencarian informasi seperti Starting, Chaining, Browsing, Differentiating, Monitoring, Extracting dan ending dengan model yang dikemukakan oleh David Ellis.

\section{Saran}

Berdasarkan hasil penelitian, beberapa saran yang penulis ajukan adalah sebagai berikut:

1. Bagi mahasiswa disarankan untuk melakukan monitoring terhadap setiap jurnal yang digunakan, dengan cara melihat daftar terbitan secara berkala dan mengikuti perkembangan jurnal tersebut setiap terbit.

2. Bagi perpustakaan Universitas Sari Mutiara diharapkan untuk menambah koleksi jurnal-jurnal terbitan terbaru secara berkala, karena berdasarkan hasil penelitian mahasiswa berpendapat bahwa perpusatakaan tidak selalu dapat memenuhi kebutuhan informasi mahasiswa.

3. Bagi Universitas Sari Mutiara Indonesia, diharapkan untuk lebih memperhatikan perpustakaan agar mahasiswa lebih tertarik dan menyadari bahwa perpustakaan adalah salah satu sumber informasi yang dibutuhkan mahasiswa.

4. Melihat pemanfaatan informasi yang positif, maka dianjurkan Mahasiswa Fakultas Ekonomi dan Ilmu Sosial Tingkat Akhir lebih meningkatkan pemanfaatan informasi. 


\section{DAFTAR PUSTAKA}

Arikunto, Suharsimi. 2006. Prosedur Penelitian: Suatu Pendekatan Praktik: Jakarta, Rineka Cipta.

Brodjonegoro, S.S., 2010. Peran Perguruan Tinggi dalam Meningkatkan Daya Saing Bangsa, Jakarta, Dikti Depdiknas.

Dewi, E. M. dan Yunus W. N. Prahatmaja (2012). Perilaku Pencarian Informasi Melalui Internet oleh Fanbase Boyband Super Junior. eJurnal Mahasiswa Universitas Padjadjaran. Vol. 1. No. 1

Ellis, 2003. Modeling the Information-Seeking Behavior of Social Scientists, 54(6):570-587. Journal Of The American Society For Information Science And Technology. onlinelibrary.wiley. com/doi/10.1002/asi. (diakses 12 maret 2018).

Herlina, Sri Suriana, dan Misroni. (2015). Perilaku Pencarian Informasi Mahasiswa Program Doktoral Universitas Islam Negeri Raden Fatah Dalam Penyusunan Disertasi. Tamaddun. Vol. XIV, No. 2

Istiana, P. dan Sri Purwaningsih. (2016). Pemanfaatan E-journal oleh Mahasiswa: Kajian Analisis Sitasi terhadap Tesis Mahasiswa Klaster Saintek Universitas Gadjah Mada. Berkala Ilmu Perpustakaan dan Informasi. Vol. 12. hlm. 318

Muthoin, (2014). Internet dan Signifikansinya terhadap Karya Ilmiah Mahasiswa. Jurnal Penelitian. Vol. 11. hlm. 318

Riani, Nur. (2017). Model Perilaku Pencarian Informasi (Studi Literatur). Jurnal Publis. Vol. 1. No. 2

Solehat, D. S., Doddy Rusmono dan Gema Rullyana, (2016). Perilaku Pencarian Informasi Mahasiswa Pendidikan Bahasa Asing di Universitas Pendidikan Indonesia. Edulib. Tahun 6, Volume 6 No. 1 
Sugiyono. 2010. Metode Penelitian Pendidikan: Pendekatan Kualitatif, Kuantitatif, dan R\&D. Bandung: Alfabeta. 